\title{
White-Ceramic Conversion on Ti-29Nb-13Ta-4.6Zr Surface for Dental Applications
}

\author{
Akiko Obata, ${ }^{1}$ Eri Miura-Fujiwara, ${ }^{2}$ Akimitsu Shimizu, ${ }^{1}$ Hirotaka Maeda, ${ }^{3}$ Masaaki Nakai, \\ Yoshimi Watanabe, ${ }^{1}$ Mitsuo Niinomi, ${ }^{4}$ and Toshihiro Kasuga ${ }^{1}$ \\ ${ }^{1}$ Graduate School of Engineering, Nagoya Institute of Technology, Gokiso-cho, Showa-ku, Nagoya 466-8555, Japan \\ ${ }^{2}$ Graduate School of Engineering, University of Hyogo, 2167 Shosha, Himeji, Hyogo 671-2280, Japan \\ ${ }^{3}$ Center for Fostering Young and Innovative Researchers, Nagoya Institute of Technology, Gokiso-cho, Showa-ku, \\ Nagoya 466-8555, Japan \\ ${ }^{4}$ Institute for Materials Research, Tohoku University, 2-1-1 Katahira, Aoba-ku, Sendai 980-8577, Japan \\ Correspondence should be addressed to Akiko Obata; obata.akiko@nitech.ac.jp
}

Received 16 May 2013; Accepted 12 July 2013

Academic Editor: Delia Brauer

Copyright (C) 2013 Akiko Obata et al. This is an open access article distributed under the Creative Commons Attribution License, which permits unrestricted use, distribution, and reproduction in any medium, provided the original work is properly cited.

Ti-29Nb-13Ta-4.6Zr (TNTZ) alloy has excellent mechanical properties and bone conductivity. For dental application, TNTZ surfaces were converted to white oxidized layer by a simple heat treatment in air to achieve the formation of aesthetic surfaces. The oxidized layer formed by the heat treatment at $1000^{\circ} \mathrm{C}$ for $0.5 \mathrm{or} 1 \mathrm{hr}$ was whiter and joined to TNTZ substrate more strongly than that formed by the treatment at $900^{\circ} \mathrm{C}$. The layer consisted of $\mathrm{TiO}_{2}$ (rutile), $\mathrm{TiNb}_{2} \mathrm{O}_{7}$, and $\mathrm{TiTa}_{2} \mathrm{O}_{7}$ and possessed $\sim 30 \mu \mathrm{m}$ in thickness for the sample heat-treated at $1000^{\circ} \mathrm{C}$ and $\sim 10 \mu \mathrm{m}$ for that heat-treated at $900^{\circ} \mathrm{C}$. The surface average roughness and the wettability increased after the heat treatment. The spreading and proliferation level of mouse osteoblast-like cell (MC3T3-E1 cell) on the heat-treated sample were almost the same as those on as-prepared one. The cell spreading on TNTZ was better than those on pure titanium (CP Ti) regardless of the heat treatment for the samples. There was no deterioration in the in vitro cell compatibility of TNTZ after the oxidized layer coating by the heat treatment.

\section{Introduction}

Titanium (Ti) and its alloys have been developed for the use in orthopedic and dental fields, such as joints, plates, screws, and tooth roots. Ti materials show better corrosion resistance than stainless steel and Co-Cr alloys, which are used for biomedical applications, due to the stable titanium oxide films formed on their surfaces. Ti alloys are categorized as $\alpha$-type, $\alpha+\beta$-type, and $\beta$-type, according to the quantities and types of their alloying elements. Various types of $\mathrm{Ti}$ alloys have been developed, particularly $\alpha+\beta$-type and $\beta$-type alloys, which have nontoxic and nonallergic elements, and are expected to be useful for biomedical application [1-4]. Ti6Al-4V ELI alloy has been registered in ASTM standardizations and used as bone fixation plates and the stems of artificial hip joints. The ELI alloy shows significant toughness: an extremely high $0.2 \%$ offset yield strength of $895 \mathrm{MPa}$, which is higher than those of stainless steel and Co-Cr-Mo alloys [3].
Ti-29Nb-13Ta-4.6Zr (TNTZ) was developed as a low rigidity $\beta$-type alloy composed of non-toxic and non-allergic elements $[1,2]$. The mechanical properties such as tensile properties and fatigue strength of TNTZ are equal to or greater than those of Ti-6Al-4V ELI alloy. Young's modulus of TNTZ is much lower than that of the ELI alloy, which makes it the preferred material for use in bone fixators. The bone conduction ability of TNTZ is better than that of stainless steel or the Ti-6Al-4V alloy [1]. Differences in mechanical properties between implant materials and natural bone lead to negative effects, such as stress shielding [2]. The properties of TNTZ have been found to be close to those of bone and expected in medical and dental fields.

Some dental materials, for example, artificial tooth and orthodontics devices such as arch wire or bracket, are required to exhibit natural sensuousness to make teeth healthy and beautiful. There is therefore concern that TNTZ 


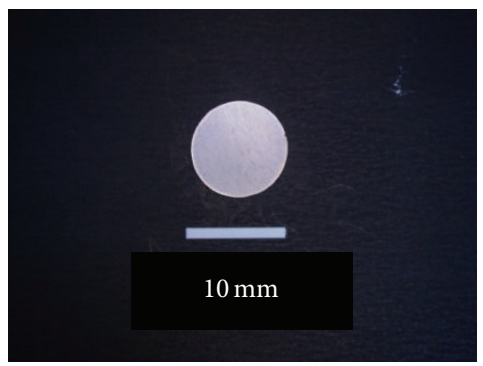

(a)

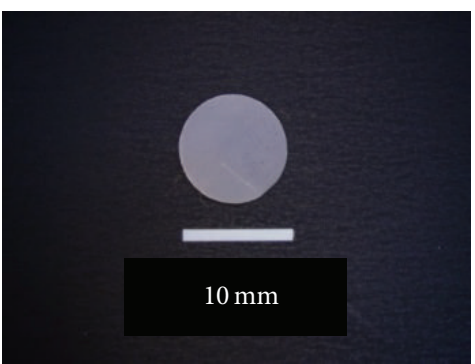

(b)

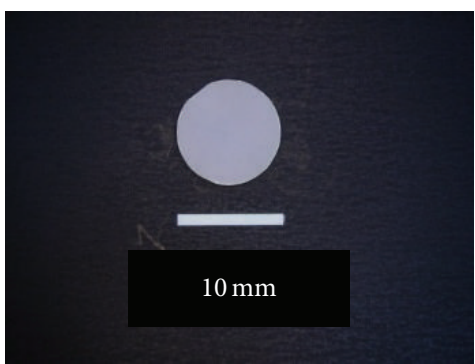

(c)

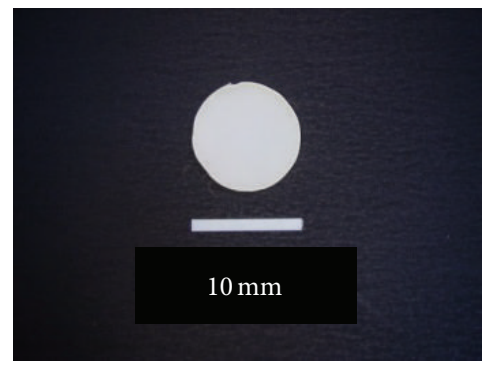

(d)

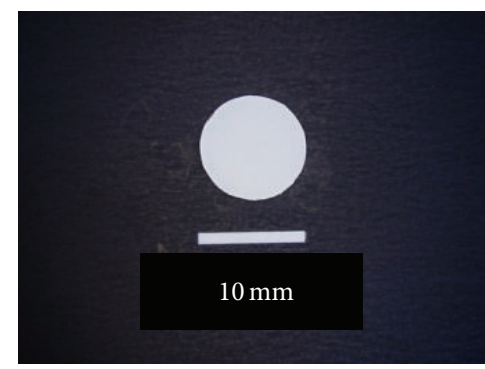

(e)

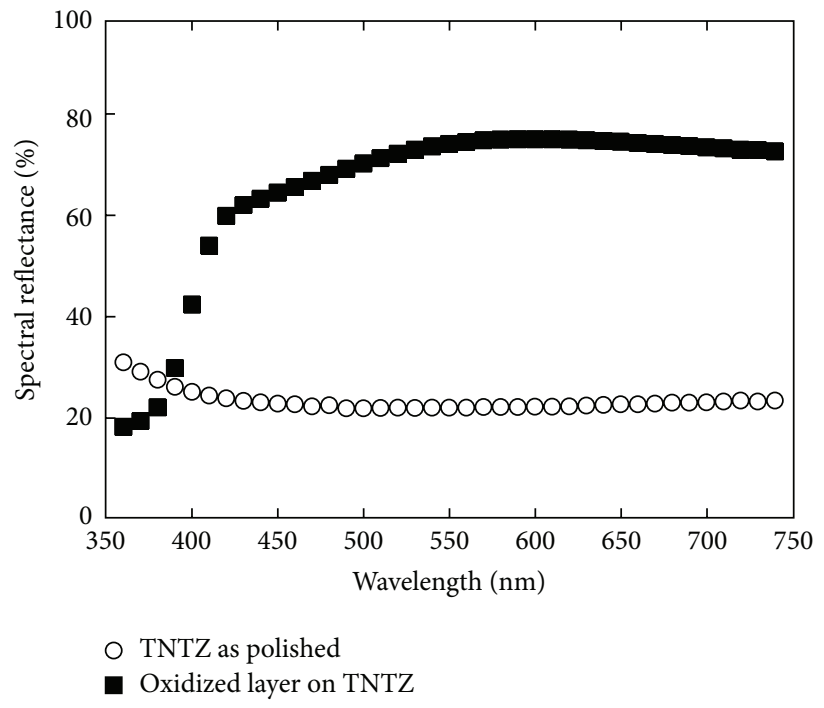

(f)

Figure 1: Appearances of TNTZ samples. (a) As-prepared, (b) heated at $900^{\circ} \mathrm{C}$ for $0.5 \mathrm{hr}$, (c) heated at $900^{\circ} \mathrm{C}$ for $1 \mathrm{hr}$, (d) heated at $1000^{\circ} \mathrm{C}$ for $0.5 \mathrm{hr}$, and (e) heated at $1000^{\circ} \mathrm{C}$ for $1 \mathrm{hr}$. Spectral reflectances of TNTZ samples before and after heat-treatment at $1000^{\circ} \mathrm{C} \mathrm{for} 0.5 \mathrm{hr}(\mathrm{f})$.

has disadvantages of aesthetic sensuousness due to its metallic colour. We believe that natural bone- or tooth-coloured coating (white-coloured coating) on TNTZ surface should be effective to solve this problem. The white-coloured coating should exhibit biocompatibility as well as or better than that of TNTZ.

Several surface modifications for Ti and Ti alloys have been performed to enhance their biocompatibilities $[3,5]$. Many pyroprocessing methods of coating hydroxyapatite (HAp), which is the main inorganic component of bone and shows an excellent biocompatibility, on the metal surfaces have been reported [6]. There is, however, concern that the prepared HAp has lower adhesion ability with the metal substrate and the coating method has limit to achieve complex-shaped metals. In addition, the HAp coating prepared by the pyroprocessing method, such as plasma spraying, exhibits lower chemical durability in body than the stoichiometric one, which attributes to an unexpected dissolution of the coating after implantation.

Calcium phosphate invert glass-ceramic $(60 \mathrm{CaO}-$ $30 \mathrm{P}_{2} \mathrm{O}_{5}-7 \mathrm{Na}_{2} \mathrm{O}-3 \mathrm{TiO}_{2}$ in mol\%) coating, which exhibits biocompatibility, for TNTZ has been reported in our previous research $[7,8]$. The coating was prepared with the following method: dipping the alloy disc into the glasspowder slurry, drying the resulting disc at $100^{\circ} \mathrm{C}$, and heating it in air at $800^{\circ} \mathrm{C}$ for $0.5 \sim 2 \mathrm{hr}$. Tensile test demonstrated 


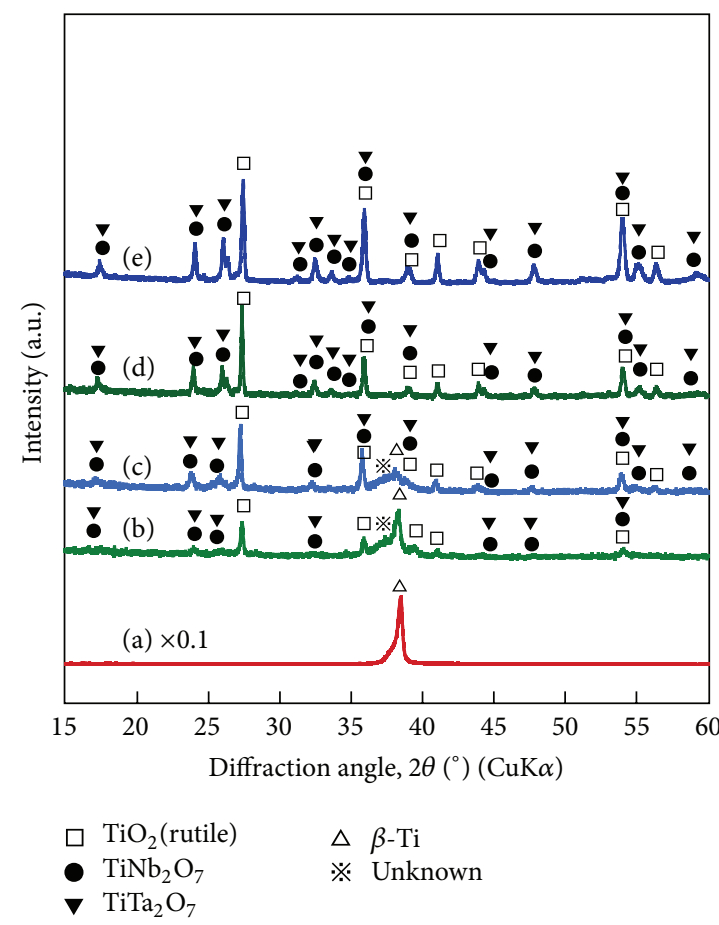

(A)

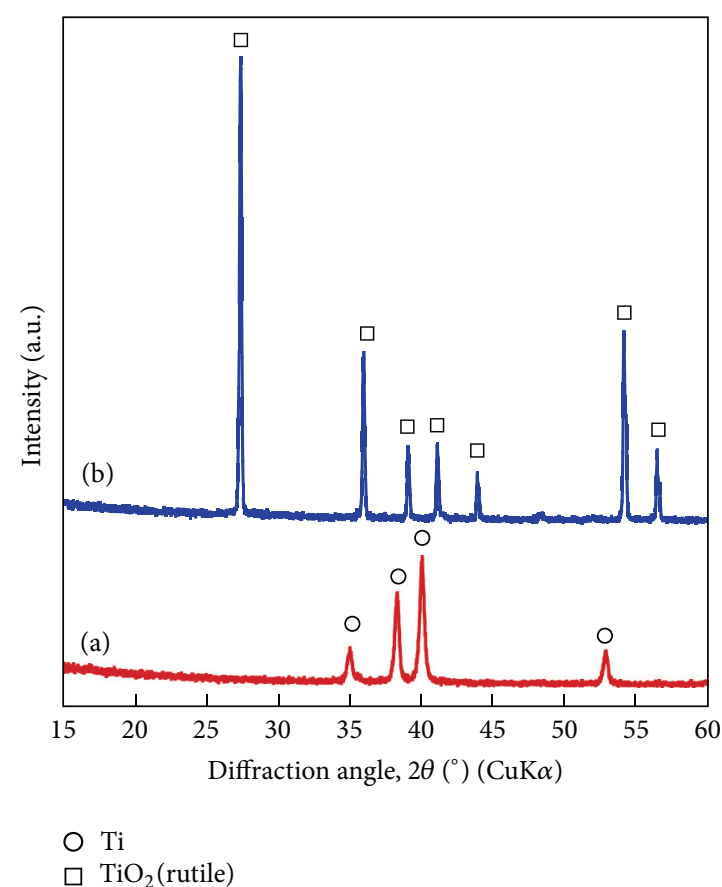

(B)

Figure 2: XRD patterns of (A) TNTZ and (B) CP Ti. (A-a) As-prepared, (A-b) heated at $900^{\circ} \mathrm{C}$ for $0.5 \mathrm{hr},(\mathrm{A}-\mathrm{c})$ heated at $900^{\circ} \mathrm{C}$ for $1 \mathrm{hr}$, (A-d) heated at $1000^{\circ} \mathrm{C}$ for $0.5 \mathrm{hr},(\mathrm{A}-\mathrm{e})$ heated at $1000^{\circ} \mathrm{C}$ for $1 \mathrm{hr},(\mathrm{B}-\mathrm{a})$ as-prepared, and $(\mathrm{B}-\mathrm{b})$ heated at $1000^{\circ} \mathrm{C}$ for $1 \mathrm{hr}$.

that the bonding strength of the coating with TNTZ was higher than that with $\mathrm{Ti}-6 \mathrm{Al}-4 \mathrm{~V}$ or pure $\mathrm{Ti}(\mathrm{CP} \mathrm{Ti})$ and the strength value $(\sim 25 \mathrm{MPa})$ was relatively higher than that of the plasma-sprayed HAp coating on CP Ti ( $\leqslant 7 \mathrm{MPa})[6]$. It was also found that an intermediate layer consisting of a thin oxidized-TNTZ layer formed between the coating and the substrate. They fractured in the glass-ceramic coating after the tensile test. This means that the bonding strength value of the oxidized layer and TNTZ substrate was higher than the measured one, which may indicate that the layer bonds to the substrate more strongly than the plasma-sprayed HAp. The oxidized layer was white because light scattering takes place at grain boundaries in its crystals. Thus, we considered that the oxidized layer can contribute the aesthetic sensuousness to TNTZ sample and the layer is able to be prepared by a simple heat treatment on the sample surface even if it has a complex shape.

The aim of the present work was to prepare whitecoloured layer by oxidization of TNTZ surfaces using a simple dry method, that is, heating TNTZ sample in air, and to evaluate its cell compatibility, particularly initial cell adhesion and proliferation, by in vitro test, using $\mathrm{CP}$ Ti or $\mathrm{TiO}_{2}$ as a comparative sample. Initial cell adhesion to substrates has been reported to influence subsequent cell events, such as proliferation, differentiation, and mineralization (in case of osteoblastic cells) [9]. The adhesion is influenced by substrate's surface properties, such as chemical component, wettability, roughness (nano micro), and topography, [914]. TNTZ has already been found to be excellent tissuecompatible by the results of in vivo tests $[1,2]$. The oxidized layer was required to be tissue-compatible as well as or better than TNTZ for the dental application, while the aforementioned surface properties would be changed from as-prepared one. In the present work, the initial adhesion, spreading, and proliferation of mouse osteoblast-like cell (MC3T3-E1 cell) on the oxidized layer on TNTZ and CP Ti were assessed and discussed with the layer's properties.

\section{Materials and Methods}

2.1. Sample Preparation. Hot rolled Ti-29Nb-13Ta-4.6Zr bars with a diameter of $10 \mathrm{~mm}$ were used as a substrate material. A solution treatment was done for the prepared TNTZ bar; that is, the material was heated to $795^{\circ} \mathrm{C}$ with a rate of temperature rising of $50^{\circ} \mathrm{C} \cdot \mathrm{min}^{-1}$ and then to $800^{\circ} \mathrm{C}$ with the rate of $1^{\circ} \mathrm{C} \cdot \mathrm{min}^{-1}$ and kept for $3 \mathrm{hr}$ at $800^{\circ} \mathrm{C}$ in $\mathrm{Ar}$ gas with an electrical furnace. TNTZ discs with $10 \mathrm{~mm}$ in diameter and $0.2 \mathrm{~mm}$ in thickness were prepared from the bar using a cutter (Accutom-50, Marumoto Struers, Japan) followed by polishing with an emery cloth (number 1500). To prepare an oxidized layer on the discs, they were set on an $\mathrm{Al}_{2} \mathrm{O}_{3}$ board, heated in air using an electrical furnace to 900 or $1000^{\circ} \mathrm{C}$ with a rate of temperature rising of $5^{\circ} \mathrm{C} \cdot \mathrm{min}^{-1}$, and kept at each temperature for 0.5 or $1 \mathrm{hr}$. $\mathrm{Ti}(\mathrm{CP} \mathrm{Ti})$ plate with the dimension of $10 \times 10 \times 0.3 \mathrm{~mm}$ was polished and heated at $1000^{\circ} \mathrm{C}$ for $1 \mathrm{hr}$ by the same conditions as those for TNTZ.

2.2. Material Characterization. Spectral reflectance of the sample surface was measured with a spectrophotometric 


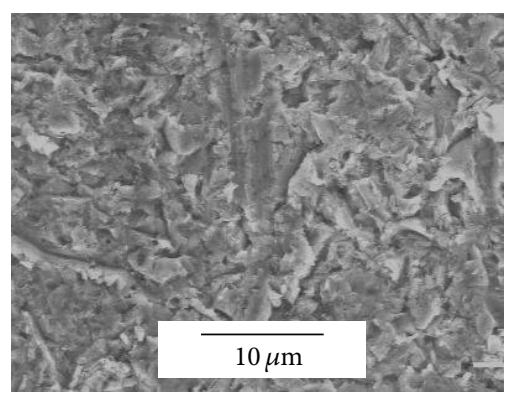

(a)

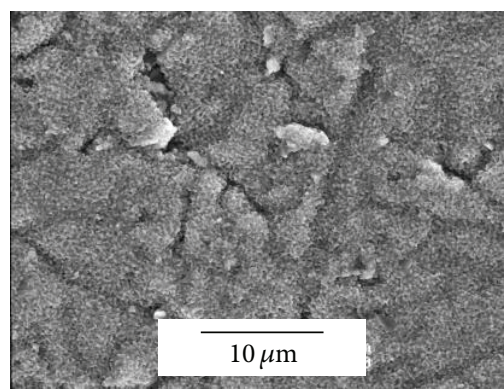

(b)

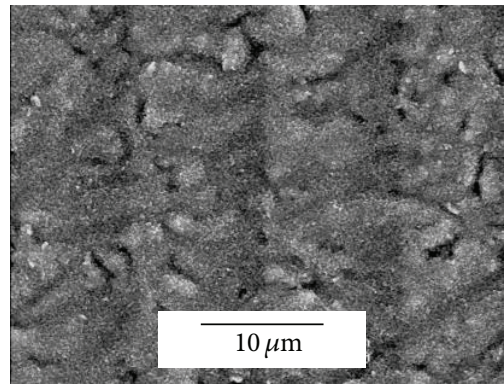

(d)

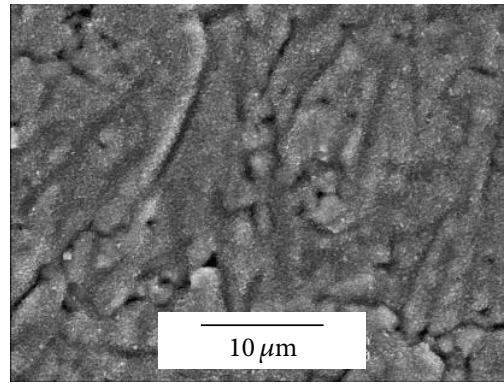

(f)

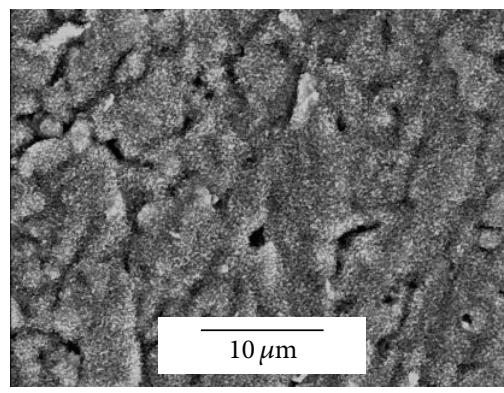

(h)

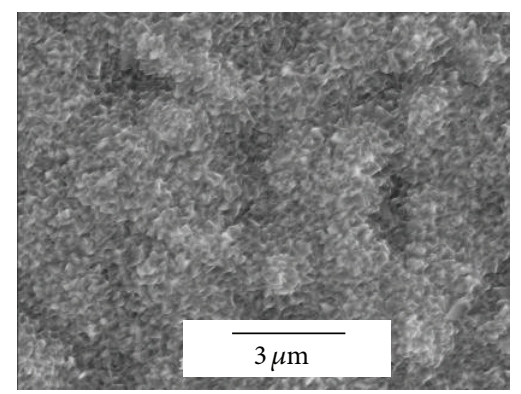

(c)

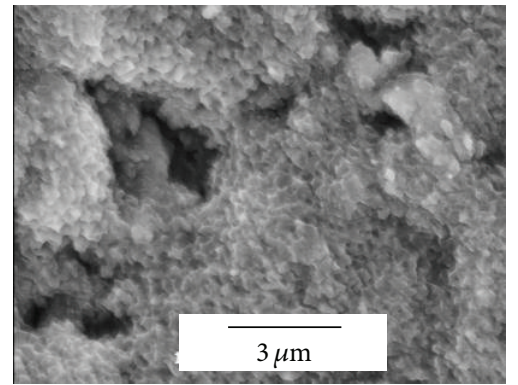

(e)

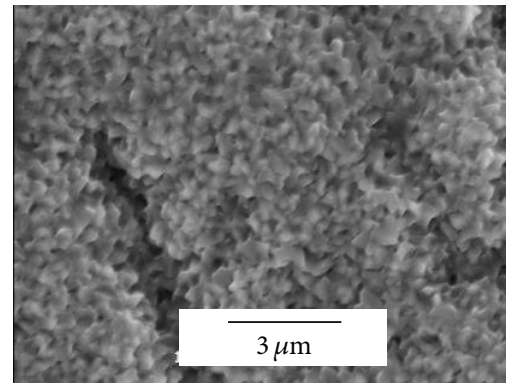

(g)

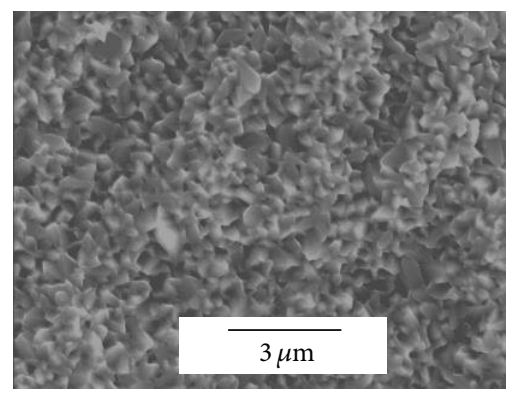

(i)

FigURE 3: SEM images of TNTZ surfaces. (a) As-prepared, (b)-(c) heated at $900^{\circ} \mathrm{C}$ for $0.5 \mathrm{hr}$, (d)-(e) heated at $900^{\circ} \mathrm{C}$ for $1 \mathrm{hr}$, (f)-(g) heated at $1000^{\circ} \mathrm{C}$ for $0.5 \mathrm{hr}$, (h)-(i) heated at $1000^{\circ} \mathrm{C}$ for $1 \mathrm{hr}$, and (c)-(i) magnified images of (b)-(h). 


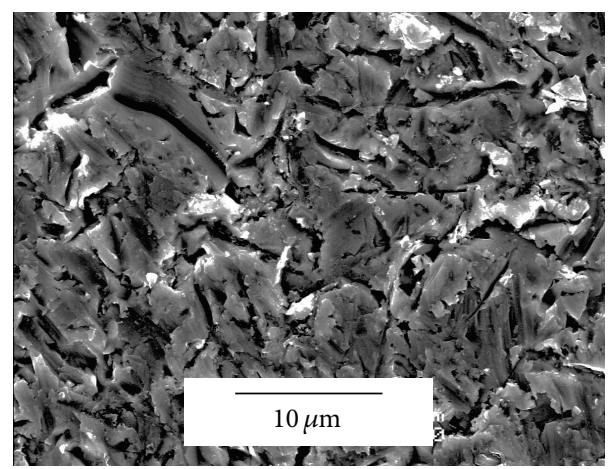

(a)

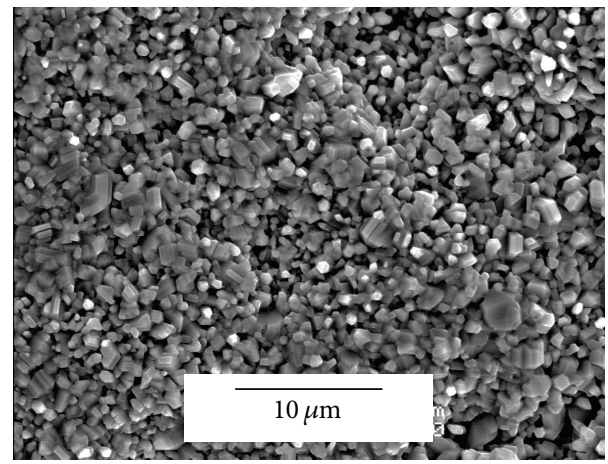

(b)

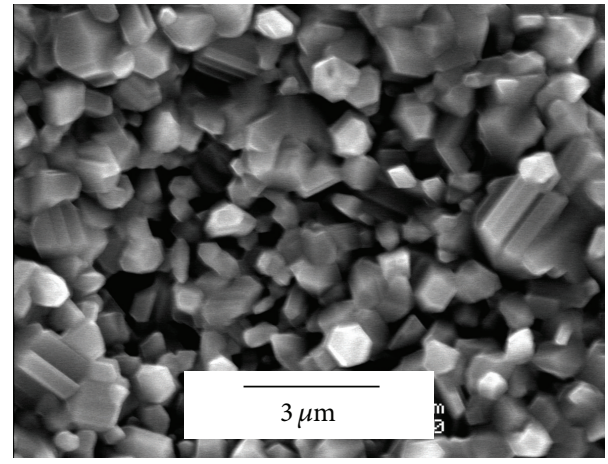

(c)

FIgURE 4: SEM images of CP Ti surfaces. (a) As-prepared, (b)-(c) heated at $1000^{\circ} \mathrm{C}$ for $1 \mathrm{hr}$, and (c) magnified image of (b).

colorimeter (CM-700, Konica Minolta). Surface morphology and cross-section of the disc were observed with scanning electron microscope (SEM, JSM-6301F, JEOL, Japan) incorporating an energy dispersive spectrometer (EDS) after coating the samples with amorphous osmium layer using a vapor deposition method (Neoc, Meiwafosis Co. Ltd., Japan). The cross-section of the samples was observed by mounting in methyl methacrylate (Technovit 4004, Okenshoji Co., Ltd., Japan) and then cut by a diamond saw. The cross-section of the samples was polished, coated with amorphous osmium, and then observed by SEM. Surface roughness was measured with a roughness measure (Surftest 401, Mitutoyo, Japan) followed by calculating an average roughness $(\mathrm{Ra})$. X-ray diffractometry (XRD) was performed on the PANalytical
(Holland) X'pert-MPD using a step size of $2 \theta: 0.017^{\circ}$ with $\mathrm{Cu} \mathrm{K} \alpha$ radiation, at $45 \mathrm{kV}$ and $40 \mathrm{~mA}$, with a count rate of $15 \mathrm{sec}$ per step, from $2 \theta$ values of $15^{\circ}$ to $60^{\circ}$. Wettability measurement was performed with a contact angle meter (DM 300, Kyowa, Japan). 10 samples were used for the measurement.

2.3. Ion Release and Cell Compatibility. The discs for cell culture tests were sterilized by heat treatment at $180^{\circ} \mathrm{C}$ for $1.5 \mathrm{hr}$ and then placed in a 24-well plate. The culture medium used was $\alpha$ MEM containing $10 \%$ fetal bovine serum (FBS). 1 $\mathrm{mL}$ of $\alpha \mathrm{MEM}$ was added to each well followed by incubation at $37^{\circ} \mathrm{C}$ in a humidified atmosphere of $95 \%$ air, $5 \% \mathrm{CO}_{2}$ for 7 days. The culture medium was changed after 1 day of incubation and then changed every other day. Ion concentration $(\mathrm{Ti}, \mathrm{Nb}, \mathrm{Ta}$, and $\mathrm{Zr}$ ) in the replaced medium was measured by inductively coupled plasma atomic emission spectroscopy (ICP-AES, ICPS-500, Shimadzu, Japan). Three samples of each sample were tested.

MC3T3-E1 cells were seeded on the disc placed in a 24well plate at a density of 50,000 cells/well and then incubated at $37^{\circ} \mathrm{C}$ in a humidified atmosphere of $95 \%$ air, $5 \% \mathrm{CO}_{2}$ for 1 day. SEM was used to monitor cell attachment and morphology. The discs after culturing were rinsed twice with phosphate buffered saline (PBS). The cells were fixed in 2.5\% glutaraldehyde for $40 \mathrm{~min}$ at $4^{\circ} \mathrm{C}$. The cells were dehydrated through a series of increasing concentrations of ethanol and dried using hexamethyldisilazane (HMDS). Samples were coated with amorphous osmium and observed with SEM. The GNU image manipulation program (GIMP2) and ImageJ software were used to calculate an individual cell area on each sample. The cell proliferation was examined after culturing for 5 days. The culture condition was aforementioned. The cell number on the sample was measured with a microplate reader (SUNRISE Remote, TECAN, Switzerland) using a Cell Counting Kit-8 (Dojindo, Japan), following its instruction. The number was counted by measuring the absorbance of the resulting medium at $450 \mathrm{~nm}$. Results represent the mean values of three samples. Thermanox was used as a control sample. Differences between groups were determined by Student $t$-test with values of $P<0.05$ considered statistically significant.

\section{Results and Discussion}

3.1. Surface Characterization. Figures 1(a) 1(e) show appearances of TNTZ before and after the heat treatments. The samples heat-treated at $1000^{\circ} \mathrm{C}$ exhibited white colour, while that heat-treated at $900^{\circ} \mathrm{C}$ showed gray colour. The results of colorimeter analysis followed this; Figure 1(f) is a typical spectral reflectance of the TNTZ before and after the heattreatment at $1000^{\circ} \mathrm{C}$ for $0.5 \mathrm{hr}$ against wavelength within the range of visible light $(400-800 \mathrm{~nm})$. Reflectance value of the oxidized surface was within $60-80 \%$ in the entire visible light range, whereas the metal surface was around $20 \%$. Generally, the higher the reflectance, the higher brightness can be obtained. Thus, the oxidized layer is much brighter than the metal surface. In addition, reflectance curve of the 


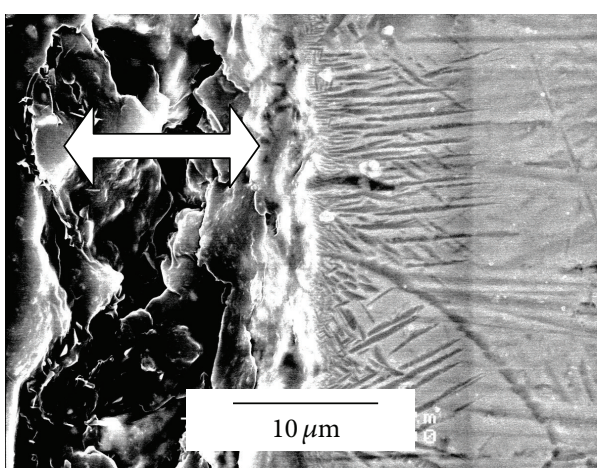

(a)

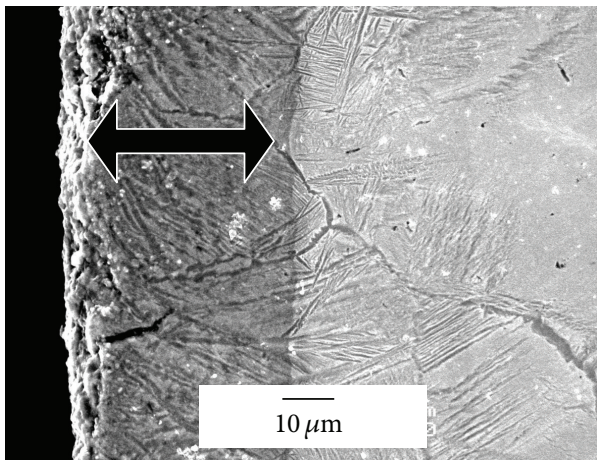

(c)

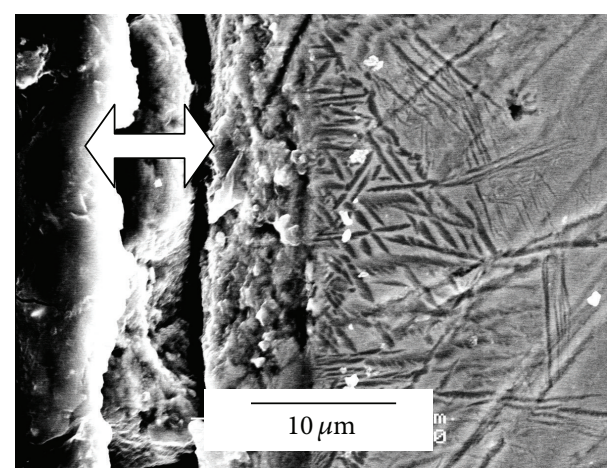

(b)

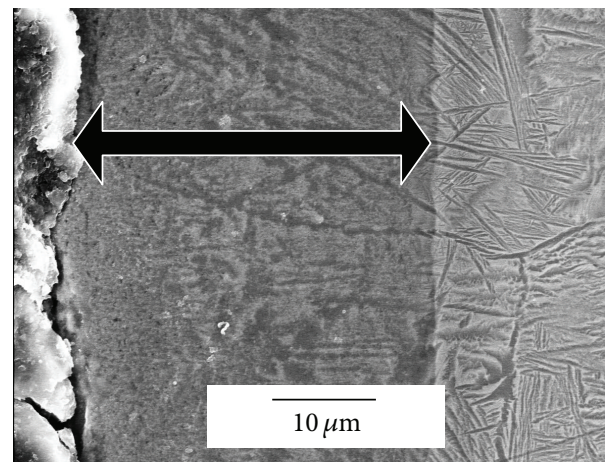

(d)

FIgure 5: Cross-sectional SEM images of TNTZ. (a) Heated at $900^{\circ} \mathrm{C}$ for $0.5 \mathrm{hr}$, (b) heated at $900^{\circ} \mathrm{C}$ for $1 \mathrm{hr}$, (c) heated at $1000^{\circ} \mathrm{C}$ for $0.5 \mathrm{hr}$, and (d) heated at $1000^{\circ} \mathrm{C}$ for $1 \mathrm{hr}$. Black arrow: oxidized layer. White arrow: gap formed after the elimination of oxidized layer through sample preparation.

oxidized surface was smooth convex upward and the maximum reflectance appeared at around 550 600 nm, where it includes wavelength component of green-yellow-orange colour. This indicates that oxidized surface colour is slightly yellowish white.

XRD patterns (Figure 2) demonstrated that the oxidized layers were formed on TNTZ and CP Ti samples after the heat treatments. The oxidized layers formed on TNTZ consisted of $\mathrm{TiO}_{2}$ (rutile), $\mathrm{TiNb}_{2} \mathrm{O}_{7}$, and $\mathrm{TiTa}_{2} \mathrm{O}_{7}$. The peak intensities corresponding to these oxidized phases increased with the increase in the treatment temperature and time; especially no $\beta$-Ti peak, which comes from the original TNTZ, was observed on the patterns of the samples heated at $1000^{\circ} \mathrm{C}$. This should be due to the change in the oxidized layer thickness. $\mathrm{TiO}_{2}$ (rutile) was predominantly formed on CP Ti after the heat treatment at $1000^{\circ} \mathrm{C}$ for $1 \mathrm{hr}$. It is difficult to identify $\mathrm{TiTa}_{2} \mathrm{O}_{7}$ phase formation on TNTZ by XRD, since both $\mathrm{TiNb}_{2} \mathrm{O}_{7}$ and $\mathrm{TiTa}_{2} \mathrm{O}_{7}$ have similar crystal structure and $\mathrm{Ta}$ amount in the alloy is small. However, Ta was not detected by EDS in the oxidized layer. Thus, we are in doubt about $\mathrm{TiTa}_{2} \mathrm{O}_{7}$ formation. If any, $\mathrm{Ta}$ could exist as $\mathrm{Ti}(\mathrm{Nb}, \mathrm{Ta})_{2} \mathrm{O}_{7}$ phase since $\mathrm{Nb}$ and $\mathrm{Ta}$ form complete solid solution [15].

Figure 3 shows SEM images of TNTZ surfaces before and after the heat treatments. Linear grooves with $\sim 1 \mu \mathrm{m}$ in size formed by polishing were observed on all samples. Particles with several hundreds $\mathrm{nm}$ in size were formed on the whole surface (in the grooves as well) of all samples after the heat treatment. Their sizes increased with the increase in the treatment temperature and time. As shown in Figure 4, in the case of CP Ti sample, rod-shaped particles with $\sim 1 \mu \mathrm{m}$ in size were formed on the whole surface after the heat treatment at $1000^{\circ} \mathrm{C}$ for $1 \mathrm{hr}$. The difference in the particle size between TNTZ and CP Ti was contributed by chemical components; $\mathrm{TiNb}_{2} \mathrm{O}_{7}$ and $\mathrm{TiTa}_{2} \mathrm{O}_{7}$ precipitation suppressed the growth of main phase (rutile) during the heat treatment in the case of TNTZ.

The cross-sectional SEM images (Figure 5) demonstrated that the oxidized layers remained on the TNTZ substrate heat-treated at $1000^{\circ} \mathrm{C}$, while they were eliminated from the surfaces heat-treated at $900^{\circ} \mathrm{C}$ through the sample preparation for the SEM observation. The reason why the layers on the samples heat-treated at $900^{\circ} \mathrm{C}$ were eliminated was unclear; however, thermal stress at the interface due to difference in their coefficients of thermal expansion is probably concerned with it. On the other hand, the elimination was suggested to be caused by the processing of SEM observation, such as cutting, polishing, and keeping in vacuum. In any case, the oxidized layer formed by the heat-treatment at $1000^{\circ} \mathrm{C}$ was found to possess better adhesion than that formed at $900^{\circ} \mathrm{C}$. Elimination behavior of the oxidized layer during oxidation, its bonding strength, and hardness will be discussed in another paper. The oxidized layer thicknesses were found to be $\sim 10 \mu \mathrm{m}$ for the samples heat-treated at $900^{\circ} \mathrm{C}$ and $\sim 30 \mu \mathrm{m}$ for one heat-treated at $1000^{\circ} \mathrm{C}$, respectively. 


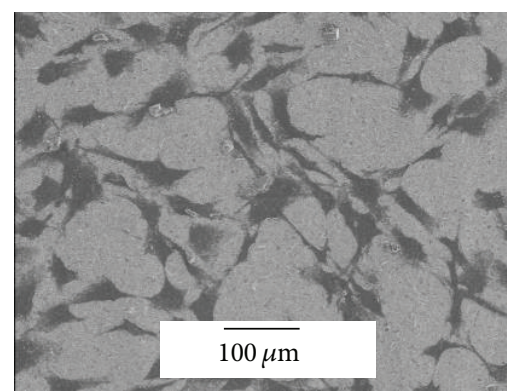

(a)

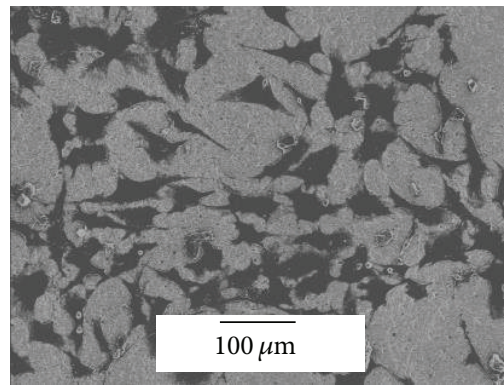

(c)

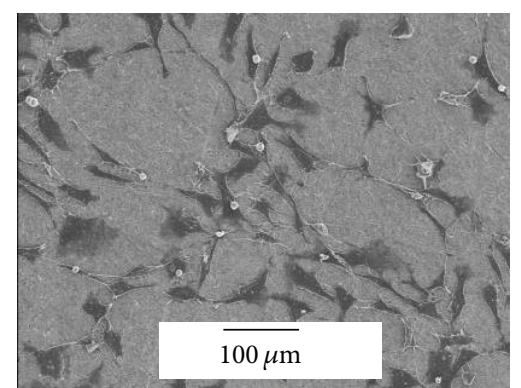

(b)

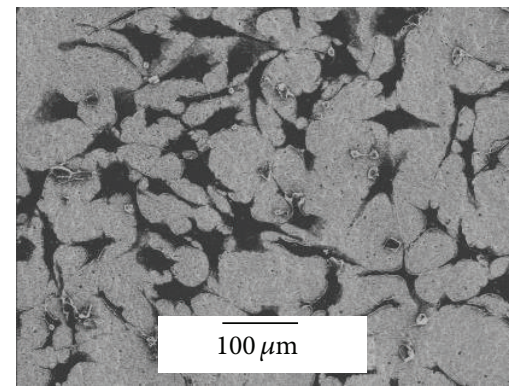

(d)

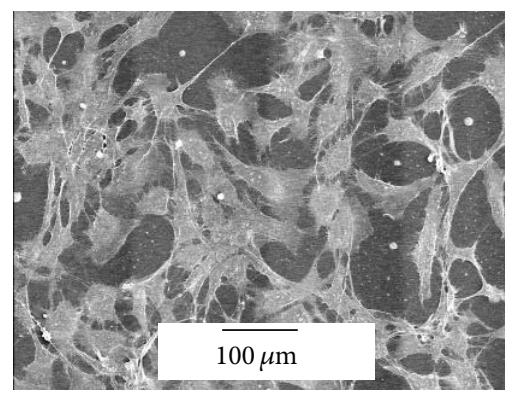

(e)

Figure 6: SEM images of cells cultured on TNTZ or CP Ti surfaces. (a) As-prepared TNTZ, (b) as-prepared CP Ti, (c) TNTZ heated at $1000^{\circ} \mathrm{C}$ for $1 \mathrm{hr},(\mathrm{d}) \mathrm{CP}$ Ti heated at $1000^{\circ} \mathrm{C}$ for $1 \mathrm{hr}$, and (e) control sample (Thermanox).

This difference in the layer thickness may contribute to the change in the appearance colour (Figure 1). Thus, TNTZ heattreated at $1000^{\circ} \mathrm{C}$ for $1 \mathrm{hr}$ was used for the subsequent surface characterization and cell culture tests.

Table 1 shows the surface properties, average roughness, and wettability of TNTZ and CP Ti samples before and after the heat treatment at $1000^{\circ} \mathrm{C}$ for $1 \mathrm{hr}$. The roughness increased and the contact angle decreased after the heat treatment in both cases of TNTZ and CP Ti. It was reported that contact angle of rutile powder was about $4 \sim 5^{\circ}$ [16]. The increased wettability may be due to the increased roughness and $\mathrm{TiO}_{2}$ contained in the oxidized layer. Surface wettability largely depends on surface energy [17]. According to the literatures [18], hydrophilic Ti has higher surface energy than the hydrophobic one and resulted in more rapid cell activation and differentiation.

3.2. Cell Attachment and Morphology. Some metallic ions released from implant materials have been reported to
TABLE 1: Average roughness (Ra) and wettability of TNTZ and CP Ti before and after heat treatment.

\begin{tabular}{lcc}
\hline Sample & $\mathrm{Ra}(\mu \mathrm{m})$ & Contact angle $\left(^{\circ}\right)$ \\
\hline TNTZ & 0.62 & 53.7 \\
$\mathrm{CP} \mathrm{Ti}$ & 0.58 & 50.3 \\
Heat-treated TNTZ $\left(1000^{\circ} \mathrm{C} 1 \mathrm{hr}\right)$ & 1.97 & 3.7 \\
Heat-treated $\mathrm{CP} \mathrm{Ti}\left(1000^{\circ} \mathrm{C} 1 \mathrm{hr}\right)$ & 1.74 & 5.9 \\
\hline
\end{tabular}

influence cell functions [19-22]. The results of ICP-AES demonstrated that no ions were released from the heattreated TNTZ in the cell culture medium. The SEM images of the cells (Figure 6) demonstrated that they spread on all sample surfaces in 1-day culture and possessed spindle and branched shapes. More spindle-shaped cells were observed on as-prepared CP Ti surface than the other samples. Figure 7 shows the individual cell area calculated using the SEM images. The area of TNTZ was larger than that of $\mathrm{CP} \mathrm{Ti}$ 


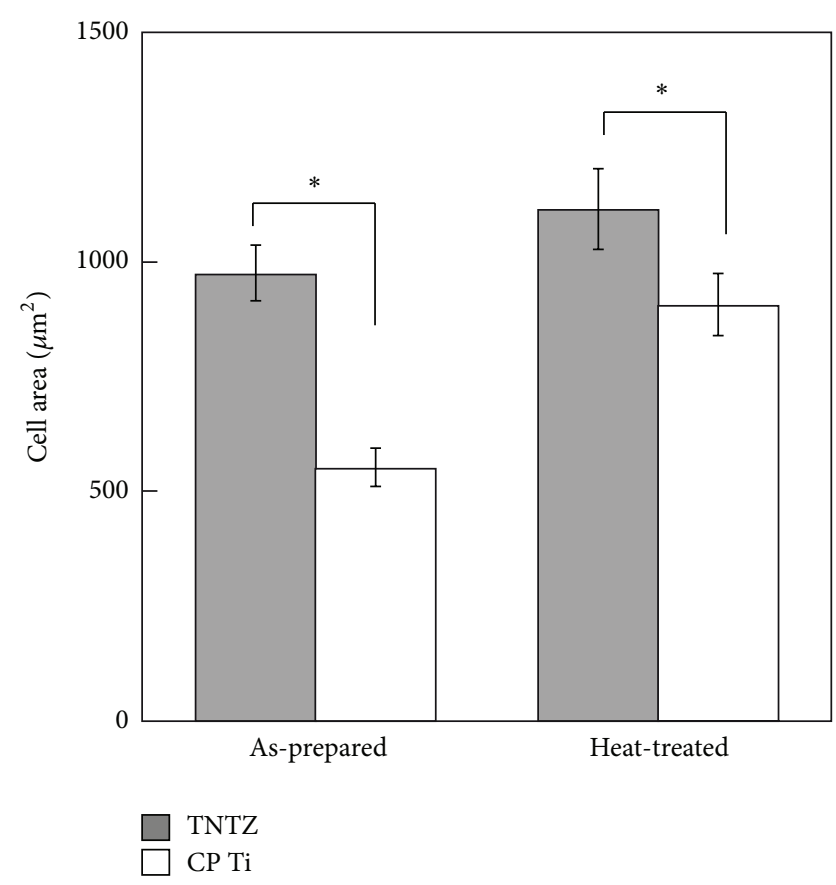

FIgURE 7: Individual cell area after culturing on TNTZ or CP Ti surface for 1 day. Heat treatment condition: $1000^{\circ} \mathrm{C}, 1 \mathrm{hr}$.

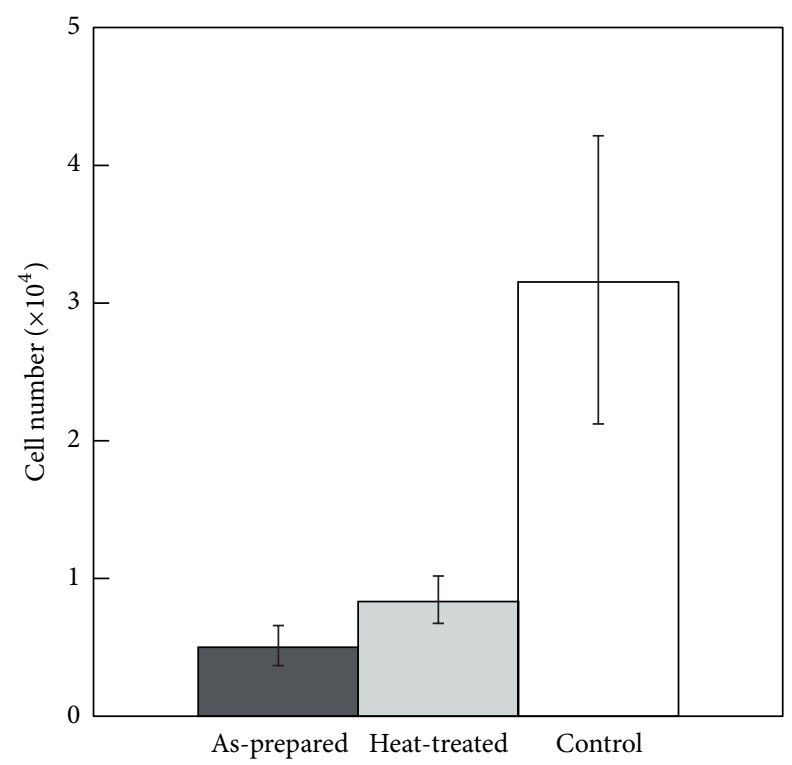

FIgURE 8: Live cell numbers on TNTZ samples after 5-day culture. Control: Thermanox. Heat treatment condition: $1000^{\circ} \mathrm{C}, 1 \mathrm{hr}$.

regardless of the heat treatment for the samples, which indicates that the cells will spread on TNTZ. The area of the heat-treated samples was larger than that of the as-prepared one in both cases of TNTZ and CP Ti samples, while there was no significant difference in the values in the case of TNTZ. The cells on TNTZ surface maintained higher performance than that on $\mathrm{CP} \mathrm{Ti}$ even after the oxidized layer coating. Figure 8 shows the live cell numbers on TNTZ samples after 5-day culture. The number of the heat-treated sample was slightly larger, while there was no significant difference in the numbers between the as-prepared and heat-treated samples. Hence, there was no deterioration in the in vitro cell compatibility of TNTZ after the oxidized layer coating by the heat treatment. In future work, human osteogenic cells will be used for the cell compatibility test instead of MC3T3-E1 cells to simulate in vivo conditions better.

The slight increase in the cell spreading area (Figure 7) and the live cell number (Figure 8) on the heat-treated samples may be due to their larger roughness and higher wettability. The cell morphology and cytoskeletal formation have been reported to relate to subsequent events, such as proliferation and differentiation [9-14]. This could be regulated by the activity and interaction of protein associated with cytoskeleton and focal adhesion. For example, the adsorption of fibronectin, which is one of extracellular matrix proteins, was reported to be favoured on hydrophobic surfaces and influenced by the substrate surface roughness [11]. Changes in cell morphology were reported to be significant in the regulation of the Hippo pathway which plays an important role in regulation of cell proliferation [23]. Stress fibers inhibit the Hippo pathway upstream of or at Lats which is one of the protein kinases in cell membrane, resulting in the upregulation of cell proliferation. The flat and spread morphology of cells promotes the formation of stress fibers (F-actin). The cell activity on the oxidized layer formed on TNTZ will be investigated in detail in future work.

\section{Conclusion}

The white-coloured coating consisting of the oxidized layer was prepared on TNTZ discs by heat treatment in air to achieve the formation of aesthetic surface on them for dental application. TNTZ has excellent mechanical properties and biocompatibility. The oxidized layer formed by the heat treatment at $1000^{\circ} \mathrm{C}$ was white-coloured and joined to TNTZ substrate more strongly than that formed by the treatment at $900^{\circ} \mathrm{C}$. The particles with the size of several hundreds $\mathrm{nm}$ containing $\mathrm{TiO}_{2}$ (rutile), $\mathrm{TiNb}_{2} \mathrm{O}_{7}$, and $\mathrm{TiTa}_{2} \mathrm{O}_{7}$ were formed during the treatment. The layer thickness was $\sim 30 \mu \mathrm{m}$ for the sample heat-treated at $1000^{\circ} \mathrm{C}$. The surface average roughness and the wettability increased after the heat treatment. The spreading and proliferation level of MC3T3-E1 cells on the heat-treated sample were almost the same as those on asprepared one. Hence, there was no deterioration in the in vitro cell compatibility of TNTZ after the oxidized layer coating by the simple heat treatment.

\section{Conflict of Interests}

No potential conflict of interests was disclosed.

\section{Acknowledgment}

This work was supported in part by Grant-in-Aid for Scientific Research (C) (no. 24560857-51) from Japan Society for Promotion of Science and Institute of Ceramics Research and Education (ICRE). 


\section{References}

[1] M. Niinomi, T. Hattori, K. Morikawa et al., "Development of low rigidity $\beta$-type titanium alloy for biomedical applications," Materials Transactions, vol. 43, no. 12, pp. 2970-2977, 2002.

[2] M. Niinomi, M. Nakai, and J. Hieda, "Development of new metallic alloys for biomedical applications," Acta Biomaterialia, vol. 8, no. 11, pp. 3888-3903, 2012.

[3] T. Hanawa, "Research and development of metals for medical devices based on clinical needs," Science and Technology of Advanced Materials, vol. 13, no. 6, Article ID 064102, 2012.

[4] C. Veiga, J. P. Davim, and A. J. R. Loureiro, "Properties and applications of titanium alloys: a brief review," Reviews on Advanced Materials Science, vol. 32, no. 2, pp. 133-148, 2012.

[5] K. Kuroda and M. Okido, "Hydroxyapatite coating of titanium implants using hydroprocessing and evaluation of their osteoconductivity," Bioinorganic Chemistry and Applications, vol. 2012, Article ID 730693, 2012.

[6] Y. C. Tsui, C. Doyle, and T. W. Clyne, "Plasma sprayed hydroxyapatite coatings on titanium substrates. Part 1: mechanical properties and residual stress levels," Biomaterials, vol. 19, no. 22, pp. 2015-2029, 1998.

[7] T. Kasuga, M. Nogami, M. Niinomi, and T. Hattori, "Bioactive calcium phosphate invert glass-ceramic coating on $\beta$-type Ti29Nb-13Ta-4.6Zr alloy," Biomaterials, vol. 24, no. 2, pp. 283-290, 2003.

[8] T. Kasuga, M. Nogami, and M. Niinomi, "Joining of calcium phosphate invert glass-ceramics on a $\beta$-type titanium alloy," Journal of the American Ceramic Society, vol. 86, no. 6, pp. 10311033, 2003.

[9] S. Lavenus, P. Pilet, J. Guicheux, P. Weiss, G. Louarn, and P. Layrolle, "Behaviour of mesenchymal stem cells, fibroblasts and osteoblasts on smooth surfaces," Acta Biomaterialia, vol. 7, no. 4, pp. 1525-1534, 2011.

[10] S. Faghihi, F. Azari, A. P. Zhilyaev, J. A. Szpunar, H. Vali, and M. Tabrizian, "Cellular and molecular interactions between MC3T3-E1 pre-osteoblasts and nanostructured titanium produced by high-pressure torsion," Biomaterials, vol. 28, no. 27, pp. 3887-3895, 2007.

[11] G. Zhao, A. L. Raines, M. Wieland, Z. Schwartz, and B. D. Boyan, "Requirement for both micron- and submicron scale structure for synergistic responses of osteoblasts to substrate surface energy and topography," Biomaterials, vol. 28, no. 18, pp. 2821-2829, 2007.

[12] H. M. Kowalczyńska and M. Nowak-Wyrzykowska, "Modulation of adhesion, spreading and cytoskeleton organization of 3T3 fibroblasts by sulfonic groups present on polymer surfaces," Cell Biology International, vol. 27, no. 2, pp. 101-114, 2003.

[13] A. Diener, B. Nebe, F. Lüthen et al., "Control of focal adhesion dynamics by material surface characteristics," Biomaterials, vol. 26, no. 4, pp. 383-392, 2005.

[14] A. Okumura, M. Goto, T. Goto et al., "Substrate affects the initial attachment and subsequent behavior of human osteoblastic cells (Saos-2)," Biomaterials, vol. 22, no. 16, pp. 2263-2271, 2001.

[15] T. B. Massalski, J. L. Murray, L. H. Bennett, and H. Baker, Binary Alloy Phase Diagram, 2nd edition, 1986.

[16] T. Mitsui and S. Takada, "On factors influencing dispersibility and wettability of powder in water," Journal of the Society of Cosmetic Chemists, vol. 20, pp. 335-351, 1969.

[17] D. V. Kilpadi and J. E. Lemons, "Surface energy characterization of unalloyed titanium implants," Journal of Biomedical Materials Research, vol. 28, no. 12, pp. 1419-1425, 1994.
[18] C. Eriksson, H. Nygren, and K. Ohlson, "Implantation of hydrophilic and hydrophobic titanium discs in rat tibia: cellular reactions on the surfaces during the first 3 weeks in bone," Biomaterials, vol. 25, no. 19, pp. 4759-4766, 2004.

[19] A. Yamamoto, R. Honma, and M. Sumita, "Cytotoxicity evaluation of 43 metal salts using murine fibroblasts and osteoblastic cells," Journal of Biomedical Materials Research, vol. 39, no. 2, pp. 331-340, 1998.

[20] M. Ikeuchi, A. Ito, Y. Dohi et al., "Osteogenic differentiation of cultured rat and human bone marrow cells on the surface of zinc-releasing calcium phosphate ceramics," Journal of Biomedical Materials Research A, vol. 67, no. 4, pp. 1115-1122, 2003.

[21] X. Wang, L. Yuan, J. Huang, T.-L. Zhang, and K. Wang, "Lanthanum enhances in vitro osteoblast differentiation via pertussis toxin-sensitive Gi protein and ERK signaling pathway," Journal of Cellular Biochemistry, vol. 105, no. 5, pp. 1307-1315, 2008.

[22] A. Hoppe, N. S. Güldal, and A. R. Boccaccini, "A review of the biological response to ionic dissolution products from bioactive glasses and glass-ceramics," Biomaterials, vol. 32, no. 11, pp. 2757-2774, 2011.

[23] K.-I. Wada, K. Itoga, T. Okano, S. Yonemura, and H. Sasaki, "Hippo pathway regulation by cell morphology and stress fibers," Development, vol. 138, no. 18, pp. 3907-3914, 2011. 

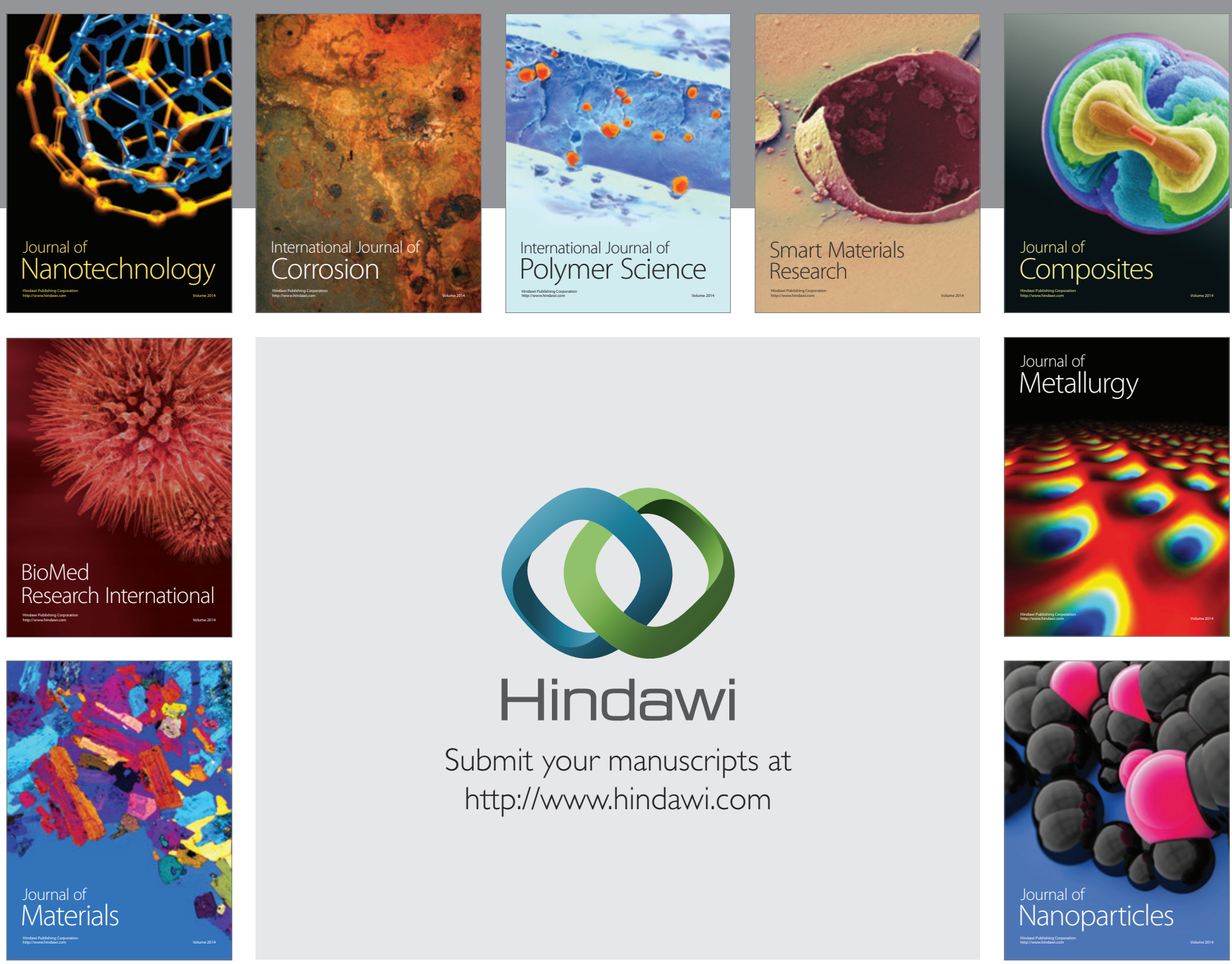

Submit your manuscripts at http://www.hindawi.com
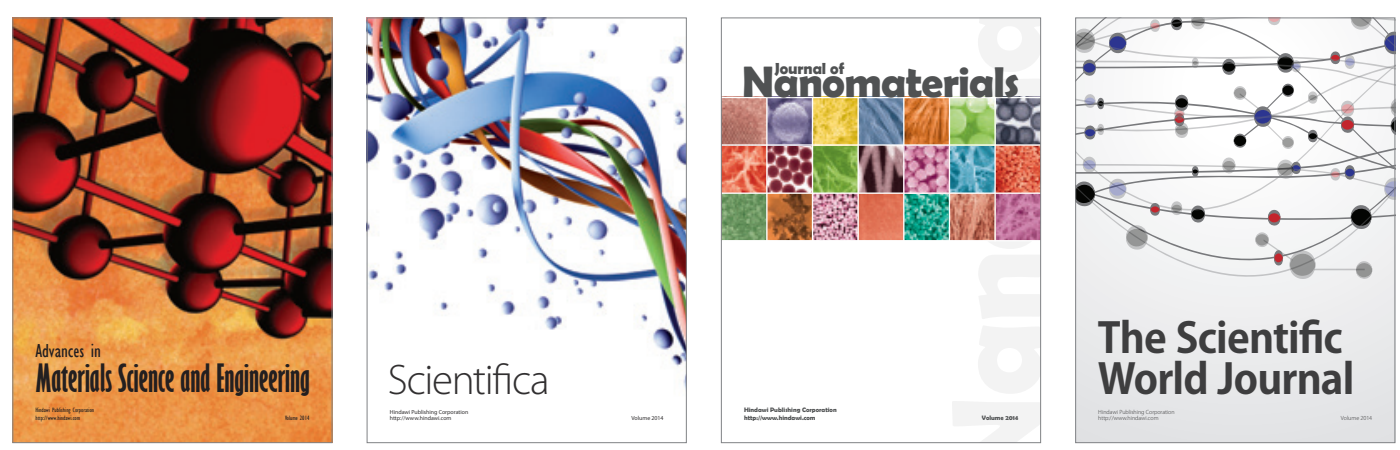

\section{The Scientific World Journal}
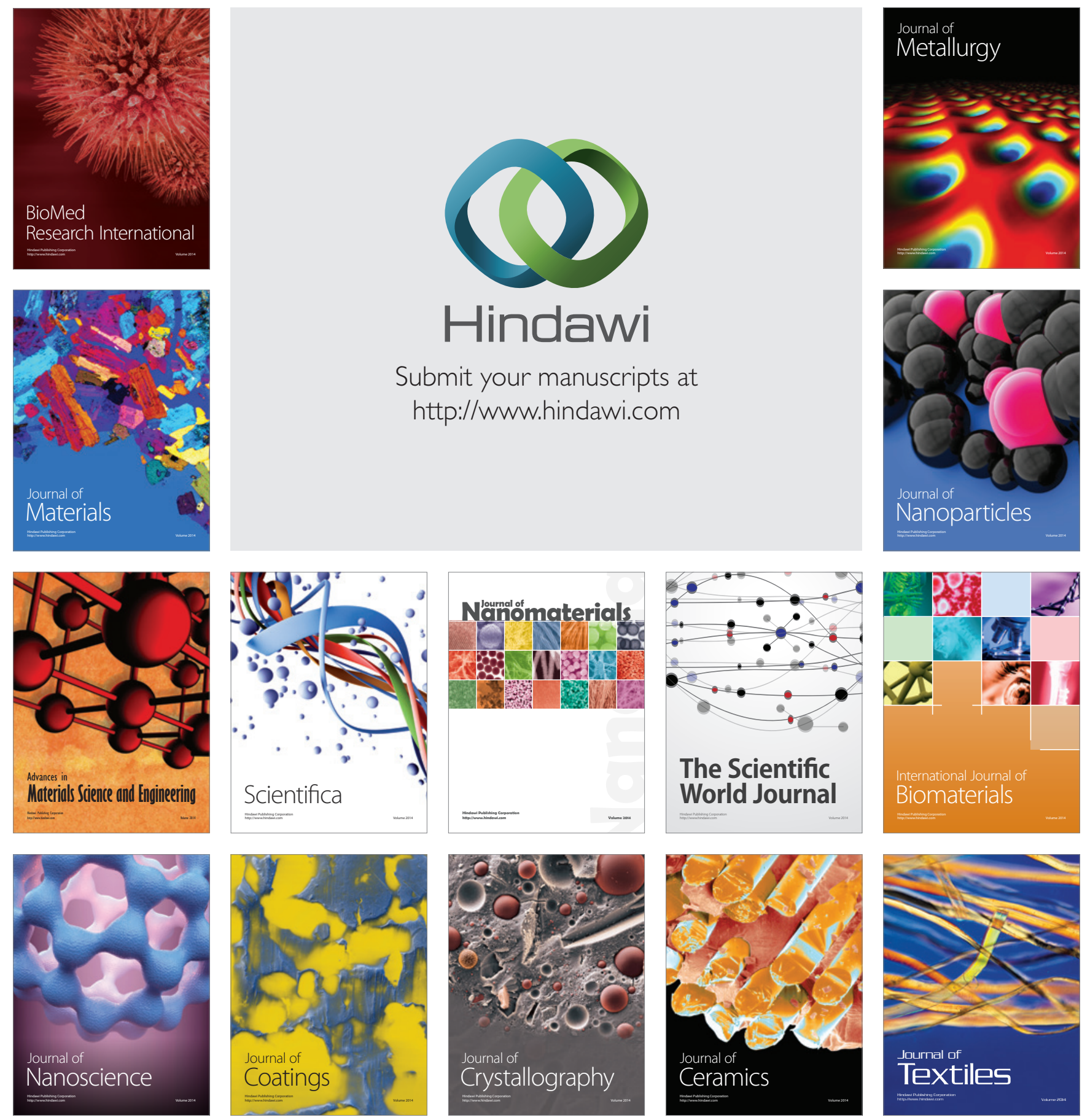